\title{
Analysis of Increasing Customer Value Through Quality of Service and Consumer Perception (Study of Indomaret Tangerang customers)
}

\author{
Ismayudin Yuliyzar \\ Fakultas Ekonomi dan Bisnis Universitas Muhammadiyah Tangerang \\ Jalan Perintis Kemerdekaan 1 Babakan no.33 Tangerang-Banten 15118
}

\begin{abstract}
The development of modern retail has increasing rapidly. The increase in modern retail is influenced by the increasing number of consumers who want to shop easily and comfortably. The purpose of this study was to determine the effect of service quality and consumer perceptions of customer value on Indomaret consumers in Permata villa Tangerang. Data collection was obtained from distributing questionnaires and processed using SPSS software version 24. The sample of this study was 72 respondents of Indomaret villa Permata consumers, the method used was incidental sampling. The results of this study partially address the Service Quality Variable (X1) has a positive effect on Customer Value (Y) because the value of $t$ is 9,656> from t table of 1.66691. Consumer Perception (X2) has a positive effect on Customer Value (Y) because the value of $t$ arithmetic of 8.620> of t table of 1.66691. Simultaneously Service Quality Variable (X1) and Consumer Perception (X2) have a positive effect on Customer Value (Y) because the calculated F value of 62.670, with a coefficient of determination of 0.654 , or $65.4 \%$ is the remainder influenced by factors not researched.
\end{abstract}

Keywords - Service Quality, Consumer Perception, Customer Value

DOI: $10.7176 / \mathrm{JMCR} / 62-03$

Publication date: November $30^{\text {th }} 2019$

\section{INTRODUCTION}

Competition among companies will never end, they always compete to improve companies that are more advanced and make each other superior to each other, so the company absolutely must have a competitive advantage in a market. Currently the development of the Indonesian retail industry is experiencing rapid development. Rapidly. The retail industry is one of the many industries that experience very fierce competition, this can be shown by the increasing number of business players entering this industry sector.

Therefore service quality must be the main focus of company attention. Quality service is comparable to the price offered by Indomaret and consumers are satisfied with the services provided and the benefits obtained from Indomaret in Tangerang Regency because it can be used as a shopping place that is fairly good, then consumers from Tangerang Regency will give a positive or high perception towards Indomaret in Tangerang Regency, because consumers feel they gain value or benefit from products or services towards Indomaret in Tangerang Regency in accordance with what is in their minds is called consumer perception. Consumer perception can provide value to its customers if Indomaret provides products with good value, employees who serve friendly, and satisfying service will provide positive value to Indomaret then it will be able to increase customer value. Based on the description above, it is necessary to conduct research under the title "Service Quality and Consumer Perception

\section{THEORY}

According to Kasmir (2017: 71) Good service is the ability of companies to provide services that can provide services that can provide satisfaction to customers in accordance with their needs and desires.

According to Kotler and Keller (2014: 179) Perception (perception) is the process by which we choose, organize, and translate input information to create a meaningful picture of the world. According to Sudaryono (2014: 70) Perception is the essence of communication, because if it is inaccurate, we might not communicate effectively. It is perception that determines we choose one message and ignore another message.

According to Gunawa Adisaputro (2014: 65) Customer value is the difference between all the benefits expected by a customer and all costs to obtain an offer for a product and the various alternatives it perceives.

\section{RESEARCH METHODS}

According to Sugiyono (2017: 2) Research methodology is basically a scientific way to get data with specific purposes and uses.

Based on this there are four keywords that need to be considered, namely, the scientific method, data, purpose, and usability. 
Population and Sample

According to Sugiyono (2017: 80), Population is a generalization area consisting of: objects or subjects that have certain qualities and characteristics determined by researchers to be studied and then drawn conclusions. In this study the population is Indomaret customers, amounting to 72 respondents. According sugiyono (2017: 81) the sample is part of the number and characteristics possessed by the population. In this study the sample technique used was incidental sampling. According to Sugiyono (2017: 85) Incidental sampling is a sampling technique based on coincidence that is, whoever happens to meet with a researcher can be used as a sample, if it is deemed that the person met by chance is suitable as a source of data.

Data analysis method

Validity test

According to Sugiyono (2017: 267) validity is the degree of accuracy between the data that occurs in the object of research with data that can be reported by researchers. Thus valid data is "no different" data between data reported by researchers with data that actually occurs on the object of research

Reliability Test

According to Maman Abdurahman (2017: 56) an instrument is said to be reliable if its measurement is consistent and accurate. So the instrument reliability test is carried out with goals to determine the consistency of the instrument as a measurement tool, so that the results of a measurement can be trusted.

Bivariate Regression Analysis

Birivat regression analysis is a method used to predict the relationship between one independent variable (predictor variable) and one dependent variable.

Multiple Regression Analysis

Multiple regression is a versatile and "powerful" analysis method that can be used to model the simultaneous effect of Service Quality (X1), Consumer Perception (X2) variables, on the dependent variable (Customer) Value (Y).

Simple Correlation Analysis

Simple correlation coefficient shows how much the relationship that occurs between two or more variables.

Multiple Correlation Analysis

Correlation test is a statistical technique used to test whether or not there is a relationship between the dependent variable $(\mathrm{Y}=$ customer value $)$ and the independent variable $(\mathrm{X} 1=$ service quality and $\mathrm{X} 2=$ consumer perception).

Analysis of the Coefficient of Determination

The coefficient of determination $\left(\mathrm{r}^{2}\right)$. Used to find out how much influence the independent variable and the dependent variable, it is necessary to know the coefficient of determination $\mathrm{r} 2$ because the measured value of the independent variable consists of the value of the absolute ratio and the comparison value, the use of r2 is to measure the percentage of the independent variable and the dependent variable.

Hypothesis testing

According to Sugiyono (2017: 63) Hypothesis is a temporary answer to the research problem formulation, where the research problem formulation has been stated in the form of sentence questions. $T$ test is used to determine whether each independent variable individually significantly influences the dependent variable. The $f$ test is the significance test of the equation used to find out how much influence the independent variable $\left(\mathrm{X}_{-}(1)\right.$ and $\mathrm{X}_{-}$ (2)) together on the dependent variable (Y).

\section{RESULTS AND DISCUSSION}

The variables in this study consist of Service Quality and Consumer Perception as an independent variable and Customer Value as the dependent variable. The variable data is obtained from the questionnaire that has been distributed. 
Table 4.4

Service Quality (X1)

\begin{tabular}{|c|c|c|c|c|c|c|}
\hline $\begin{array}{c}\text { Item } \\
\text { Statement }\end{array}$ & SS (5) & S (4) & KS (3) & TS (2) & STS (1) & TOTAL \\
\hline X1.1 & 34 & 19 & 16 & 3 & 0 & 72 \\
\hline XI.2 & 31 & 22 & 18 & 1 & 0 & 72 \\
\hline X1.3 & 15 & 39 & 11 & 6 & 1 & 72 \\
\hline X1.4 & 34 & 22 & 8 & 8 & 0 & 72 \\
\hline XI.5 & 34 & 20 & 11 & 4 & 3 & 72 \\
\hline X1.6 & 33 & 18 & 19 & 1 & 1 & 72 \\
\hline X1.7 & 32 & 24 & 11 & 4 & 1 & 72 \\
\hline XI.8 & 33 & 22 & 7 & 9 & 1 & 72 \\
\hline X1.9 & 16 & 39 & 13 & 4 & 0 & 72 \\
\hline X1.10 & 18 & 31 & 22 & 1 & 0 & 72 \\
\hline
\end{tabular}

Table 4.5

Consumer behavior (X2)

\begin{tabular}{|c|c|c|c|c|c|c|}
\hline $\begin{array}{c}\text { Item } \\
\text { Statement }\end{array}$ & SS (5) & S (4) & KS (3) & TS (2) & STS (1) & TOTAL \\
\hline X2.1 & 26 & 28 & 13 & 5 & 0 & 72 \\
\hline X2.2 & 12 & 34 & 23 & 3 & 0 & 72 \\
\hline X2.3 & 34 & 23 & 9 & 5 & 1 & 72 \\
\hline X2.4 & 13 & 35 & 15 & 8 & 1 & 72 \\
\hline X2.5 & 32 & 24 & 9 & 3 & 4 & 72 \\
\hline X2.6 & 7 & 43 & 20 & 1 & 1 & 72 \\
\hline$X 2.7$ & 18 & 37 & 13 & 2 & 2 & 72 \\
\hline$X 2.8$ & 15 & 20 & 26 & 11 & 0 & 72 \\
\hline$X 2.9$ & 19 & 37 & 13 & 2 & 1 & 72 \\
\hline X2.10 & 34 & 20 & 15 & 3 & 0 & 72 \\
\hline
\end{tabular}


Table 4.6

Customer value (Y)

\begin{tabular}{|c|c|c|c|c|c|c|}
\hline Item & SS (5) & S (4) & KS (3) & TS (2) & STS (1) & TOTAL \\
\hline Y.1 & 29 & 15 & 27 & 1 & 0 & 72 \\
\hline Y.2 & 32 & 10 & 22 & 6 & 2 & 72 \\
\hline Y.3 & 32 & 9 & 23 & 8 & 0 & 72 \\
\hline Y.4 & 19 & 33 & 17 & 3 & 0 & 72 \\
\hline Y.5 & 32 & 25 & 11 & 3 & 1 & 72 \\
\hline Y.6 & 29 & 20 & 18 & 3 & 2 & 72 \\
\hline Y.7 & 19 & 31 & 16 & 5 & 1 & 72 \\
\hline Y.8 & 31 & 9 & 23 & 7 & 2 & 72 \\
\hline Y.9 & 16 & 37 & 16 & 2 & 1 & 72 \\
\hline Y.10 & 34 & 7 & 27 & 4 & 0 & 72 \\
\hline
\end{tabular}

Validity test

All research variables contain 30 statements that must be answered by respondents. To determine and assess the validity of each item can be seen from the Pearson correlation value of each item. In this study, using a sample of 72 respondents. For the validity of each statement of each of the variables of this study used the formula with a significant level of $5 \%(0.05)$ :

$\mathrm{DF}=72-2=70$, then the $\mathrm{r}$ table is 0.2319 . The results of the validity test variable Service Quality (X1), Consumer Perception (X2) and purchasing decisions (Y). So if the $r$ table is greater than $r$ count it can be said to be valid, and vice versa if it is lower than $r$ table can be said to be invalid.

Test Results of Service Quality Variable Validity (X1)

\begin{tabular}{|c|c|c|c|c|}
\hline Variable & Item & rtest & r Table & remarks \\
\hline \multirow{4}{*}{$\begin{array}{c}\text { Service quality } \\
\text { ( X1) }\end{array}$} & Q 1 & 0,832 & 0,2319 & Valid \\
\cline { 2 - 5 } & Q 2 & 0,641 & 0,2319 & Valid \\
\cline { 2 - 5 } & Q 3 & 0,581 & 0,2319 & Valid \\
\cline { 2 - 5 } & Q 4 & 0,781 & 0,2319 & Valid \\
\cline { 2 - 5 } & Q5 & 0,692 & 0,2319 & Valid \\
\cline { 2 - 5 } & Q 6 & 0,717 & 0,2319 & Valid \\
\cline { 2 - 5 } & Q 7 & 0,753 & 0,2319 & Valid \\
\cline { 2 - 5 } & Q 8 & 0,787 & 0,2319 & Valid \\
\cline { 2 - 5 } & Q 9 & 0,697 & 0,2319 & Valid \\
\cline { 2 - 5 } & Q 10 & 0,744 & 0,2319 & Valid \\
\hline
\end{tabular}




\begin{tabular}{|c|c|c|c|c|}
\hline \multicolumn{5}{|c}{ Test result validity test consumer perception (X2) } \\
\hline \multirow{4}{*}{ Variable } & Item & rtest & r Table & remarks \\
\hline \multirow{5}{*}{ Consumer Perception (X2) } & Q 1 & 0,790 & 0,2319 & Valid \\
\cline { 2 - 5 } & Q 2 & 0,529 & 0,2319 & Valid \\
\cline { 2 - 5 } & Q 3 & 0,738 & 0,2319 & Valid \\
\cline { 2 - 5 } & Q 4 & 0,624 & 0,2319 & Valid \\
\cline { 2 - 5 } & Q5 & 0,765 & 0,2319 & Valid \\
\cline { 2 - 5 } & Q 6 & 0,514 & 0,2319 & Valid \\
\cline { 2 - 5 } & Q 7 & 0,705 & 0,2319 & Valid \\
\cline { 2 - 5 } & Q 8 & 0,575 & 0,2319 & Valid \\
\cline { 2 - 5 } & Q 9 & 0,694 & 0,2319 & Valid \\
\cline { 2 - 5 } & Q 10 & 0,811 & 0,2319 & Valid \\
\hline
\end{tabular}

Test Result validity test consumer value (Y)

\begin{tabular}{|c|c|c|c|c|}
\hline Variable & Item & rtest & r Table & remarks \\
\hline \multirow{4}{*}{$\begin{array}{c}\text { Customer value } \\
\text { (Y) }\end{array}$} & Q 1 & 0,610 & 0,2319 & Valid \\
\cline { 2 - 5 } & Q 2 & 0,570 & 0,2319 & Valid \\
\cline { 2 - 5 } & Q 3 & 0,549 & 0,2319 & Valid \\
\cline { 2 - 5 } & Q 4 & 0,659 & 0,2319 & Valid \\
\cline { 2 - 5 } & Q5 & 0,723 & 0,2319 & Valid \\
\cline { 2 - 5 } & Q 6 & 0,638 & 0,2319 & Valid \\
\cline { 2 - 5 } & Q 7 & 0,609 & 0,2319 & Valid \\
\cline { 2 - 5 } & Q 8 & 0,617 & 0,2319 & Valid \\
\cline { 2 - 5 } & Q 9 & 0,609 & 0,2319 & Valid \\
\cline { 2 - 5 } & Q 10 & 0,631 & 0,2319 & Valid \\
\hline
\end{tabular}

Reliability Test

In this study the Cronbach's Alpha facility was used in SPSS version 24 software. A variable is said to be reliable if it gives a Cronbach's Alpha value> 0.60 .

Reabilitas test

\begin{tabular}{|c|c|c|c|}
\hline Variable & Cronbach's Alpha & Standard Reabilitas & Status \\
\hline Service quality & 0,927 & 0,60 & Reliable \\
\hline Consumer perception & 0,910 & 0,60 & Reliable \\
\hline Consumer value & 0,884 & 0,60 & Reliable \\
\hline
\end{tabular}

Simple and Multiple Regression Analysis

1. In the analysis results of the $\mathrm{X} 1$ regression of the $\mathrm{Y}$ constant of 10,123, it implies that the constant value of the customer value variable is 10.123 . The regression coefficient $\mathrm{X} 1$ is 0.723 so it can be said that the direction of the influence of the $\mathrm{X} 1$ variable on $\mathrm{Y}$ is positive.

2. In the results of the regression analysis of X2 to Y Constant of 10.356, it means that the constant value of the customer value variable is 10.356 .

3. In the results of multiple regression analysis $\mathrm{X} 1, \mathrm{X} 2$ to $\mathrm{Y}$, the constant value is 4.948. Service Quality Variable (0.476) and Consumer Perception (0.388) on Consumer Value. Based on the regression coefficient value for each variable, it can be explained that the greater influence variable on Customer Value is the Service Quality variable which has a greater regression coefficient (0.476) compared to the Consumer Perception variable (0.388).

Simple and Multiple Correlation Analysis

Test service quality (X1) to consumer value (Y)

Model Summary

\begin{tabular}{|l|c|r|r|r|}
\hline Model & R & R Square & Adjusted R Square & Std. Error of the Estimate \\
\hline 1 & $.756^{\mathrm{a}}$ & .571 & .565 & 4.640 \\
\hline
\end{tabular}

From the table above, it can be seen that the relationship between Service Quality and Customer Value has a fairly strong level of relationship that is 0.756 . 
Correlation Results of Consumer Perception (X2) on Customer Value (Y)

\begin{tabular}{|c|c|c|c|c|}
\hline Model & R & R Square & Adjusted R Square & Std. Error of the Estimate \\
\hline 1 & $.718^{\mathrm{a}}$ & .515 & .508 & 4.935 \\
\hline
\end{tabular}

Model Summary

From the table above, it is known that the relationship between Consumer Perceptions of Customer Value has a strong relationship level of 0.718 .

Model Summary

\begin{tabular}{|c|c|c|c|c|}
\hline Model & R & R Square & Adjusted R Square & Std. Error of the Estimate \\
\hline 1 & $.803^{\mathrm{a}}$ & .645 & .635 & 4.252 \\
\hline & & & & \\
\hline
\end{tabular}

From the table above, it can be seen that the relationship between Service Quality and Consumer Perception on Customer Value has a strong level of closeness that is equal to 0.803 .

Analysis of the Coefficient of Determination

The coefficient of determination analysis is used to find out how much the independent variable (X) can explain the dependent variable (Y)

From the results of the calculation of the coefficient of determination above obtained R2 (R square) of 0.645 , meaning that $64.5 \%$ of customer value variables can be explained by service quality and consumer perceptions. The remaining $35.6 \%$ is explained by other variables outside the variables used.

Partial T Test T (Partial)

Hypothesis testing, or better known as partial testing, is used to test the effect of each independent partially on the dependent variable.

1. From the results of the above persial t calculation that the variable Service Quality (X1) produces a $t$ count of 9,656 and a significant value of 0,000 . At the significance level of 0,000 and degrees of freedom $(\mathrm{df})=\mathrm{n}-2 \mathrm{or}$ $72-2=70$, a value of $t$ table of 0.2319 with alpha of 0.5 or $5 \%$ is obtained. Because the $t$ value of $9,656>$ of $t$ table of 0.2319 , it can be concluded that the hypothesis "there is a positive and significant effect between service quality $(\mathrm{X} 1)$ on customer value $(\mathrm{Y})$ " is accepted.

2. From the results of the above persial $t$ calculations that the Consumer Perception variable (X2) produces a $t$ count of 8.620 and a significance value of 0.000 . At the significance level of 0,000 and degrees of freedom $(\mathrm{df})=$ $\mathrm{n}-2$ or $72-2=70$, a value of $\mathrm{t}$ table of 0.2319 with alpha of 0.5 or $5 \%$ is obtained. Because the $t$ value is $8.620>$ from $t$ table 0.2319 , it can be concluded that the hypothesis "there is a significant and positive influence between Consumer Perception (X2) on Customer Value (Y)" is accepted.

Simultaneous F Test

To find out the influence of independent variables together on the dependent variable

From the ANOVA results obtained a calculated $F$ value of 62.670 and a significant value of 0.000 . At a significant level of 0,000 and degrees of freedom $(\mathrm{df} 2)=\mathrm{n}-\mathrm{k}-1$ or $72-\mathrm{k}-1=69$ then $\mathrm{F}$ table 3.13 means $\mathrm{F}$ count $>\mathrm{F}$ table, then the regression model can be used to predict Customer Value (Y) or it can be said that the variable Service Quality (X1), Consumer Perception (X2), together have a significant effect on customer value received.

\section{CONCLUSION}

Based on the results of the analysis and discussion described previously, it can be concluded that the overall results of the study are as follows:

1. This research results in an influence between Service Quality and Customer Value. Evidenced by the acquisition of a regression equation $\mathrm{Y}=10.123+0.723 \mathrm{X}$

2. This research results in an influence between Consumer Perception and Customer Value. Evidenced by the acquisition of a regression equation $\mathrm{Y}=10.356+0.744 \mathrm{X}$

3. This research results in an influence between Service Quality and Consumer Perception with Customer Value. Evidenced by the acquisition of a regression equation $\mathrm{Y}=4.948+0.476 \mathrm{X}_{1}+0.388 \mathrm{X}_{2}$.

\section{RECOMMENDATION}

Based on the conclusions of this research, the following suggestions can be submitted:

1. The company is expected to be able to improve service quality and consumer perceptions as well as other factors that support customer value for services that have been purchased so as not to feel disappointed and lead to a loyal attitude towards the company.

2. The management must also focus and pay attention to the perceptions that arise in the minds of consumers of the company by always giving a good and friendly impression so that the store's image in the eyes of consumers is maintained. 


\section{References}

Abdul Rauf dan Ismayudin Yuliyzar. 2016. Manajemen Pemasaran. CV Grafika Arta Nwala : Jakarta.

Basu dan Hani. 2018. Manajemen Pemasaran Analisis Perilaku Konsumen. BPFE Yogyakarta.

Donni Juni Priansa. 2017. Perencanaan dan Pengembangan Sumber DayaManusia.Alfabeta : Bandung

Dwi Suhartanto. 2014. Metode Riset Pemasaran. Alfabeta : Bandung.

George R. Terry. 2014. Dasar-Dasar Manajemen. Bumi Aksara : Jakarta.

Gunawan Adisaputro. 2014. Manajemen Pemasaran(Analisis Untuk Perancangan Strategi Pemasaran). UPP STIM YKPN : Yogyakarta.

Kasrmir. 2017.Customer Service Excellent: Teori dan Praktik. Rajawali Pers : Jakarta.

Kotler dan Keller. 2014. diahli bahasakan oleh Bob Sabran. Manajemen Pemasaran . (Edisi Tiga Belas). Erlangga : Jakarta.

Kotler dan Keller. 2016. Manajemen Pemasaran. Erlangga : Jakarta.

Kotler dan Keller. 2018. Manajemen Pemasaran. Erlangga : Jakarta.

Malayu S.P Hasibuan. 2014. Manajemen Sumber Daya Manusia. (Cetakan Delapan Belas). Bumi Aksara : Bandung.

M Nur Nasution. 2015. Manajemen Mutu Terpadu. (Total Quality Management). Ghalia Indonesia : Bogor.

Robbins P. Stephen, Mary Coulter.2014.Management. (Edisi Dua Belas). Erlangga : Jakarta.

Sarinah dan Mardalena. 2017. Pengantar Manajemen.CV Budi Utama : Yogyakarta.

Setyaningrum, Ari, dkk. (2015). Prinsip-Prinsip Pemasaran. Andi Pubhliser : Yogyakarta.

Sugiyono. 2012. Metode Penelitian Kuantitatif,Kualitatif, dan R\&D. Bandung: Alfabeta.

Slameto. 2015. Belajar dan faktor-faktor yang mempengaruhinya. (Cetakan Keenam).PT Rineka Cipta: Jakarta. Sudaryono. 2014. Perilaku Konsumen Dalam Perspektif Pemasaran. Lentera Ilmu Cendekia : Jakarta Pusat.

Suparyanto dan Rosad. 2015. Manajemen Pemasaran. In Media : Bogor.

Terry, George R dan Rue, Leslie W.2015.Dasar-Dasar Menejemen.(Cetakan Enam Belas). PT Bumi Aksara : Jakarta.

Thamrin, HM. 2015. Pengantar Bisnis. Media Pustaka : Yogyakarta.

Tjiptono, Fandy .2014.Pemasaran Jasa.Andi : Yogyakarta 